\title{
Emergency medicine point-of-care ultrasonography: a national needs assessment of competencies for general and expert practice
}

\author{
Lisa M. Fischer, MD*; Michael Y. Woo, MD*; A. Curtis Lee, PhD*; Ray Wiss, MD; \\ Steve Socransky, $\mathrm{MD}^{\dagger}$; Jason R. Frank, MD, MA*
}

\section{ABSTRACT}

Introduction: Emergency medicine point-of-care ultrasonography (EM-PoCUS) is a core competency for residents in the Royal College of Physicians and Surgeons of Canada and College of Family Physicians of Canada emergency medicine (EM) training programs. Although EM-PoCUS fellowships are currently offered in Canada, there is little consensus regarding what training should be included in a Canadian EM-PoCUS fellowship curriculum or how this contrasts with the training received in an EM residency.

Objectives: To conduct a systematic needs assessment of major stakeholders to define the essential elements necessary for a Canadian EM-PoCUS fellowship training curriculum.

Methods: We carried out a national survey of experts in EMPoCUS, EM residency program directors, and EM residents. Respondents were asked to identify competencies deemed either nonessential to EM practice, essential for general EM practice, essential for advanced EM practice, or essential for EM-PoCUS fellowship trained ("expert") practice.

Results: The response rate was $81 \%$ (351 of 435 ). PoCUS was deemed essential to general EM practice for basic cardiac, aortic, trauma, and procedural imaging. PoCUS was deemed essential to advanced EM practice in undifferentiated symptomatology, advanced chest pathologies, and advanced procedural applications. Expert-level PoCUS competencies were identified for administrative, pediatric, and advanced gynecologic applications. Eighty-seven percent of respondents indicated that there was a need for EM-PoCUS fellowships, with an ideal length of 6 months. Conclusion: This is the first needs assessment of major stakeholders in Canada to identify competencies for expert training in EM-PoCUS. The competencies should form the basis for EM-PoCUS fellowship programs in Canada.

\section{RÉSUMÉ}

Introduction: L'échographie pratiquée au point de service en médecine d'urgence (EPS-MU) est une compétence de base pour les résidents inscrits aux programmes de formation en médecine d'urgence ( $M U$ ) du Collège royal des médecins et chirurgiens du Canada et du Collège des médecins de famille du Canada. Bien que des bourses de recherche soient offertes en EPS-MU au Canada, il existe un faible consensus quant à la formation à inclure dans un programme d'études postdoctorales en la matière ou quant à la différence de contenu entre cette dernière formation et celle donnée dans les programmes de résidence en MU.

Objectif: L'étude visait à procéder à une évaluation méthodique des besoins des principaux intervenants afin de définir les éléments essentiels d'un programme canadien de formation postdoctorale en EPS-MU.

Méthode: Une enquête nationale a été menée parmi les spécialistes en EPS-MU, les directeurs de programme de résidence en $\mathrm{MU}$ et les résidents en $\mathrm{MU}$. Les répondants devaient indiquer les compétences jugées non essentielles en $\mathrm{MU}$, essentielles en MU générale, essentielles en MU avancée et essentielles en EPS-MU (degré d' "expert»).

Résultats: Le taux de réponse a atteint $81 \%$ (351 répondants sur 435). L'EPS a été jugée essentielle en MU générale dans les cas d'imagerie de base pour des troubles cardiaques, des lésions de I'aorte, des traumas et des interventions; I'EPS a été jugée essentielle en $\mathrm{MU}$ avancée dans les cas de symptômes indifférenciés, d'affections thoraciques rendues à un stade avancé ainsi que dans des applications interventionnelles avancées. Les compétences spécialisées en EPS ont été réservées à des fins administratives et à des applications pédiatriques et gynécologiques avancées. Enfin, $87 \%$ des répondants ont indiqué qu'il y avait des besoins en matière de formation postdoctorale en EPS-MU, d'une durée idéale de 6 mois.

Conclusions: II s'agit là de la première évaluation des besoins des principaux intervenants au Canada visant à cerner les compétences à acquérir dans la formation spécialisée en EPS-MU. Ces compétences devraient former les assises des programmes d'études postdoctorales en EPSMU, au Canada.

From the *Department of Emergency Medicine, University of Ottawa, Ottawa, ON, and the +Department of Emergency Medicine, Health Sciences North, Northern Ontario School of Medicine, Sudbury, ON.

Correspondence to: Dr. Lisa M. Fischer, 1053 Carling Avenue, Room EM-206, Box 227, Ottawa, ON K1Y 4E9; lisadfischer@gmail.com.

This article has been peer reviewed. 
Keywords: education, emergency medicine, point-of-care ultrasonography

Emergency medicine point-of-care ultrasonography (EMPoCUS) is a safe and proven diagnostic imaging modality whose worldwide use has grown tremendously since being introduced in the early 1980s..$^{1-3}$ A generally accepted definition of PoCUS is "ultrasonography brought to the patient and performed by the provider in real time." Many studies have validated the usefulness of clinical, targeted ultrasound assessment performed by emergency physicians. The benefits of PoCUS include decreased time to diagnosis, ${ }^{4}$ decreased emergency department length of stay, ${ }^{5}$ improved success rates of invasive procedures, ${ }^{6}$ decreased complication rates of various procedures, ${ }^{7}$ and improved health care resource use. ${ }^{8-11}$

In Canada, there are currently two training pathways for certification in EM: 1) a 5-year EM residency through the Royal College of Physicians and Surgeons of Canada (RCPSC), leading to a specialist (FRCPC) designation, and 2) a 1-year program through the College of Family Physicians of Canada (CFPC) undertaken after an initial 2-year training and certification in family medicine. PoCUS became a core competency standard for residents of the RCPSC and CFPC EM residency programs in 2008 and 2010, respectively. 12,13 The current recommendations are that all residents be taught how to perform PoCUS; for a list of elements, see Table 1 . The Canadian Association of Emergency Physicians (CAEP), ${ }^{3}$ the Canadian Emergency Ultrasound Society (CEUS), ${ }^{14}$ the American College of Emergency Physicians (ACEP), ${ }^{1}$ and the Society for Academic Emergency Medicine (SAEM) ${ }^{15}$ have all published policy statements on the use of PoCUS.

Table 1. Current emergency medicine residency PoCUS requirements

Royal College of Physicians and Surgeons of Canada (2011)

Focused abdominal sonography for trauma (FAST)

Cardiac scans

Aortic scans

Pelvic scans to rule out ectopic pregnancy

Family medicine-emergency medicine residency programs (2010)

Facilitation of vascular access

Presence of intraperitoneal free fluid

Measurement of abdominal aorta diameter

Presence of pericardial fluid

Presence of cardiac motion

Confirmation of intrauterine gestation

PoCUS = point-of-care ultrasonography.
At the time this study was commenced (2010), there were two nationally advertised PoCUS fellowships (expert training programs) offered in Canada, one at the University of Ottawa and the other at Northern Ontario School of Medicine (NOMS) in Sudbury, and approximately 80 PoCUS fellowships offered in the United States. ${ }^{16}$ To our knowledge, other than an ACEP policy statement on PoCUS fellowship guidelines developed from expert consultation, ${ }^{1}$ little consensus, research, or stakeholder consultation exists regarding what training should be included in an EM-PoCUS fellowship curriculum. ${ }^{17}$ Recent studies have found that tremendous variability exists in current EM-PoCUS curricula, both in the United States and Canada, ${ }^{18-20}$ suggesting that guidelines are needed to ensure high-quality PoCUS training in EM residency programs. ${ }^{21}$ Increased PoCUS research and the establishment of high-quality PoCUS fellowships would support further advancement of the field and greater acceptance of PoCUS as a core competency for all emergency physicians and increase PoCUS use in academic, community, and international EM settings. ${ }^{22-24}$

The primary purpose of this study was to conduct a national systematic needs assessment to define the essential competencies for a Canadian EM-PoCUS fellowship training curriculum. Secondarily, we sought to determine which EM-PoCUS competencies were considered essential for general and advanced EM practice. Medical education needs assessments typically involve the identification of discrepancies between the current and a desired state of competence in a domain. ${ }^{25,26}$ Observed needs are those defined by individuals with special expertise in a field and can identify gaps when they assess others. Perceived needs typically relate to learners' perception of what they would like to learn to achieve greater competence in a domain. In this study, we sought to define both observed and perceived needs as identified by experts in EM-PoCUS, educational leaders, and EM trainees.

\section{MATERIALS AND METHODS}

\section{Study design and population}

This was a national bilingual (English/French) survey of three populations: 1) emergency physician experts in the field of PoCUS, 2) EM program directors (PDs), and 3) EM residents. The experts were identified from the CAEP and the CEUS databases, and all were instructors in one or more of the following national 
courses: Emergency Department Echo (EDE), Emergency Department Targeted Ultrasound (EDTU), and Focused Emergency Department Sonography (FEDS). At the time of the study, there were 13 RCPSC and 17 CFPC EM programs in Canada. ${ }^{27}$ All PDs and all 429 residents in these 30 training programs were eligible to participate. Pediatric EM specialists or trainees were not included. The study received approval from the Ottawa Hospital Research Ethics Board.

\section{Survey content and administration}

The survey instrument was developed in consultation with content experts. Items were derived from existing literature, existing training programs, and expert opinion. The survey was pilot tested with a group of four emergency physicians and four EM residents prior to distribution. The final survey consisted of three sections: demographics, competencies, and a needs assessment. Eighty-three competencies were assessed.

The study involved the simultaneous administration of two questionnaires. The first was a Web-based survey (using the commercially available online software Survey Console) of experts in EM-PoCUS and RCPSC and CFPC EM residency PDs. Distribution was carried out using a modified Dillman technique..$^{28,29}$ After an email notification, which included a consent form, participants were sent a link to the survey (Appendix, online version only). Subsequent reminder notices were sent 2 weeks apart, for a total of three contacts. To encourage participation, a random draw for a gift card was offered. The second survey was a paper-based survey of all RCPSC and CFPC EM residents in Canada. Chief residents at each program were sent the surveys and asked to distribute them to all residents present at an academic session of their choosing. The chief resident noted the total number of surveys distributed and returned the completed surveys to the principal investigator. To encourage participation, chief residents were entered into a random draw for a gift card. Medical students and residents not enrolled in an EM residency program were excluded. The survey was conducted from November 2010 to February 2011, and participation was voluntary.

\section{Data analysis}

Respondents were asked to categorize each competency into one of the following groups: "not essential to EM practice," "essential for general EM practice," "essential for advanced EM practice," or "essential for fellowshiptrained EM practice." A single data abstractor entered the results into an electronic database using Microsoft Excel. Responses were kept anonymous, and all data were reported in aggregate. Gap scores and descriptive statistics were reported. A significant gap score was defined a priori as a difference among populations of responders of greater than $20 \%$. If greater than $20 \%$ of participants identified a competency as being nonessential, it was classified as such. If greater than $70 \%$ of participants identified a competency as being essential for general, advanced, or fellowship-trained practice, it was classified as such. Responses from the three different groups were weighted prior to categorization. The experts' responses were weighted $50 \%$ of the final result, and the PDs and residents were weighted at $25 \%$ each.

\section{RESULTS}

A total of 351 of 435 surveys were completed, for an overall response rate of $80.6 \%$. Response rates for experts, PDs, and residents were $86.4 \%$ (152 of 194), $53.5 \%$ (15 of 28), and $78.4 \%$ (184 of 213), respectively. The median age in years for experts, PDs, and residents was 42.0, 46.0, and 30.6, respectively; $36.7 \%$ (129 of 435 ) of participants were female, and 8.9\% (52 of 435) responded in French.

Demographic information for the study population is provided in Table 2. The average number of years in practice for the experts and PDs was 12 years. The vast majority $(88.7 \%)$ of the experts and all of the PDs reported working primarily in an urban or inner-city EM setting, and $66 \%$ of experts worked with a mixed adult and pediatric population, compared to $66 \%$ of PDs who worked primarily with adults. Seventy-two percent of the residents were enrolled in the RCPSC EM program and $42 \%$ were postgraduate year (PGY)-3.

Figure 1 outlines the geographic distribution of participants; $62.1 \%$ were from Ontario or Quebec. Figure 2 outlines the level of PoCUS training. Almost $75 \%$ of the experts had advanced PoCUS training, whereas $70 \%$ of the program directors were credentialed in PoCUS. Eighteen percent of residents reported having no training in PoCUS, whereas 30\% were credentialed.

Table 3 provides participants' categorization of the surveyed competencies. Sixteen competencies (19.3\%) had significant gap scores, all of which arose from PDs 


\begin{tabular}{|c|c|c|c|}
\hline & Experts & Program directors & Residents \\
\hline Surveys distributed, $n$ & 194 & 28 & 213 \\
\hline Responses received, $n(\%)$ & $152(78.4)$ & $15(53.5)$ & $184(86.4)$ \\
\hline Age in years, median (range) & $42.0(29-69)$ & $46.0(39-59)$ & $30.6(25-52)$ \\
\hline Female, $n(\%)$ & $38(25)$ & $2(13)$ & $89(43.6)$ \\
\hline Year of residency, $n(\%)$ & $\mathrm{N} / \mathrm{A}$ & N/A & \\
\hline PGY-1 & & & $41(20)$ \\
\hline PGY-2 & & & 39 (19) \\
\hline PGY-3 & & & $87(42.4)$ \\
\hline$P G Y-4$ & & & $21(19.2)$ \\
\hline$P G Y-5$ & & & $14(6.8)$ \\
\hline Program of enrolment, $n(\%)$ & N/A & $\mathrm{N} / \mathrm{A}$ & \\
\hline CFCP EM & & & $56(27.9)$ \\
\hline RCPSC EM & & & $145(72.1)$ \\
\hline Language of instruction in French, $n(\%)$ & $39(25.6)$ & $1(6.6)$ & $12(5.9)$ \\
\hline Medical training/certification, $n(\%)$ & & & $\mathrm{N} / \mathrm{A}$ \\
\hline Resident & $4(2.6)$ & 0 & \\
\hline CCFP(EM) & $88(57.1)$ & $7(70)$ & \\
\hline CCFP (not EM) & $26(16.8)$ & $1(6.6)$ & \\
\hline $\mathrm{FRCP}(\mathrm{EM})$ & $25(16.2)$ & $9(60)$ & \\
\hline Other & $11(7.1)$ & $1(6.6)$ & \\
\hline Years in practice, median (range) & $12(2-45)$ & $12(4-22)$ & N/A \\
\hline Location of EM practice, $n(\%)$ & & & N/A \\
\hline Inner city & $61(40.1)$ & $6(40)$ & \\
\hline Urban/suburban & $74(48.6)$ & $9(60)$ & \\
\hline Small town & $10(6.6)$ & 0 & \\
\hline Other & $7(4.6)$ & 0 & \\
\hline Type of EM practice, $n(\%)$ & & $\mathrm{N} / \mathrm{A}$ & \\
\hline Medium volume & $1(0.6)$ & & \\
\hline High volume & $19(12.5)$ & & \\
\hline Teaching hospital & $43(28.2)$ & & \\
\hline Other & 89 (58.6) & & \\
\hline Patient population seen, $n(\%)$ & & $\mathrm{N} / \mathrm{A}$ & \\
\hline Adults & 51 (33.5) & & \\
\hline Adults and pediatrics & 101 (66.5) & & \\
\hline
\end{tabular}

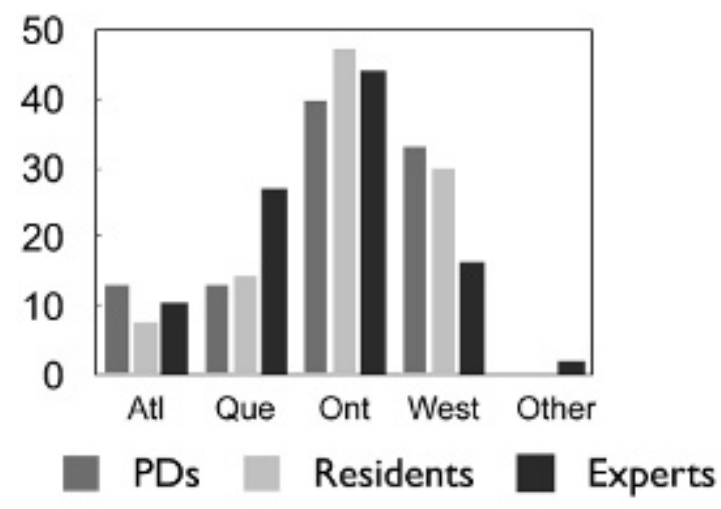

Figure 1. Geographic distribution of respondents (\%).

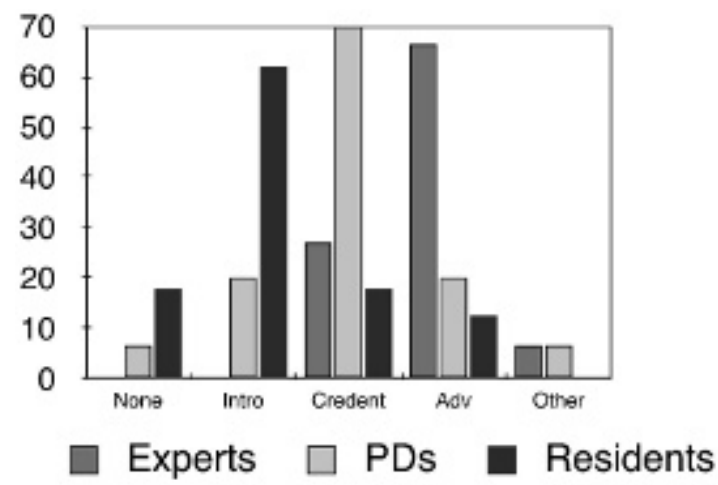

Figure 2. Level of training with PoCUS (\%). 


\begin{tabular}{|c|c|c|c|c|}
\hline & $\begin{array}{c}\text { Core EM PoCUS } \\
\text { (general EM practice) }\end{array}$ & $\begin{array}{l}\text { Advanced EM PoCUS } \\
\text { (special interest) }\end{array}$ & $\begin{array}{c}\text { Expert EM PoCUS (fellowship } \\
\text { trained) }\end{array}$ & $\begin{array}{l}\text { Not essential for EM } \\
\text { PoCUS at this time }\end{array}$ \\
\hline \multirow[t]{3}{*}{ Clinical scenarios } & Trauma (FAST) & Undifferentiated shock* & \multirow[t]{3}{*}{ Undifferentiated chest pain } & \\
\hline & \multirow[t]{2}{*}{ Cardiac arrest } & $\begin{array}{l}\text { Undifferentiated shortness } \\
\text { of breath* }\end{array}$ & & \\
\hline & & $\begin{array}{l}\text { Undifferentiated abdominal } \\
\text { pain* }\end{array}$ & & \\
\hline \multirow[t]{3}{*}{ Ultrasound physics } & $\begin{array}{l}\text { Understanding } \\
\text { differences in } \\
\text { transducers }\end{array}$ & $\begin{array}{l}\text { Understanding of relationship } \\
\text { between frequency, } \\
\text { penetration, and resolution* }\end{array}$ & \multirow[t]{3}{*}{$\begin{array}{l}\text { Use of Doppler } \\
\text { ultrasonography* }\end{array}$} & \\
\hline & $\begin{array}{l}\text { Understanding } \\
\text { image artifacts }\end{array}$ & \multirow[t]{2}{*}{$\begin{array}{l}\text { Use of M-mode } \\
\text { ultrasonography* }\end{array}$} & & \\
\hline & Basic knobology & & & \\
\hline \multirow[t]{18}{*}{ Diagnostic testing } & \multirow{3}{*}{$\begin{array}{l}\text { Pericardial effusion } \\
\text { Confirmation of } \\
\text { cardiac standstill }\end{array}$} & \multirow{2}{*}{$\begin{array}{l}\text { Assessment of global cardiac } \\
\text { activity* }\end{array}$} & \multirow{2}{*}{$\begin{array}{l}\text { Cardiac wall motion } \\
\text { abnormalities }\end{array}$} & PID \\
\hline & & & & Ovarian cyst \\
\hline & & \multirow{3}{*}{$\begin{array}{l}\text { Assessment of inferior vena } \\
\text { cava for volume status* } \\
\text { Pneumothorax* }\end{array}$} & Pulmonary edema & Tubo-ovarian abscess \\
\hline & \multirow{2}{*}{$\begin{array}{l}\text { Abdominal aortic } \\
\text { aneurysm (AAA) }\end{array}$} & & \multirow{2}{*}{$\begin{array}{l}\text { Upper extremity DVT } \\
\text { Lower extremity DVT }\end{array}$} & Epididymitis-orchitis \\
\hline & & & & Hydrocele \\
\hline & \multirow{13}{*}{$\begin{array}{l}\text { First-trimester } \\
\text { intrauterine } \\
\text { pregnancy using } \\
\text { transabdominal } \\
\text { view }\end{array}$} & \multirow{13}{*}{$\begin{array}{l}\text { Pleural effusion } \\
\text { Fetal heart rate } \\
\text { First-trimester intrauterine } \\
\text { pregnancy using } \\
\text { transvaginal view } \\
\text { Cutaneous abscess }\end{array}$} & \multirow{13}{*}{$\begin{array}{l}\text { Acute arterial occlusion } \\
\text { Ovarian torsion } \\
\text { Testicular torsion } \\
\text { Cholecystitis } \\
\text { Choledocholithiasis } \\
\text { Peritonsillar abscess* } \\
\text { Achilles tendon tears } \\
\text { Retinal detachment }\end{array}$} & Testicular mass \\
\hline & & & & Appendicitis \\
\hline & & & & Diverticulitis \\
\hline & & & & Bowel obstruction \\
\hline & & & & Pancreatitis \\
\hline & & & & Intussuception* \\
\hline & & & & $\begin{array}{l}\text { Hypertrophic pyloric } \\
\text { stenosis* }\end{array}$ \\
\hline & & & & Abdominal/inguinal hernias \\
\hline & & & & Rotator cuff tears \\
\hline & & & & Extremity fractures \\
\hline & & & & $\begin{array}{l}\text { Optic nerve sheath } \\
\text { diameter } \\
\text { for intracranial pressure }\end{array}$ \\
\hline & & & & $\begin{array}{l}\text { Posterior vitreous } \\
\text { detachment }\end{array}$ \\
\hline & & & & Retrobulbar hematoma \\
\hline \multirow[t]{10}{*}{ Procedures } & \multirow[t]{10}{*}{ Central line placement } & $\begin{array}{l}\text { Foreign body localization } \\
\text { in soft tissues }\end{array}$ & \multirow[t]{10}{*}{ Regional anesthesia } & $\begin{array}{l}\text { Foreign body localization in } \\
\text { eye }\end{array}$ \\
\hline & & Peripheral line placement* & & Confirm ETT placement \\
\hline & & Arterial line placement* & & Confirm pacemaker \\
\hline & & Thoracentesis & & placement \\
\hline & & Paracentesis & & Hematoma block \\
\hline & & Pericardiocentesis & & \\
\hline & & Arthrocentesis* & & \\
\hline & & Abscess drainage* & & \\
\hline & & Lumbar puncture & & \\
\hline & & Foreign body removal & & \\
\hline
\end{tabular}




\begin{tabular}{|c|c|c|c|c|}
\hline & $\begin{array}{c}\text { Core EM PoCUS } \\
\text { (general EM practice) }\end{array}$ & $\begin{array}{l}\text { Advanced EM PoCUS } \\
\text { (special interest) }\end{array}$ & $\begin{array}{c}\text { Expert EM PoCUS (fellowship } \\
\text { trained) }\end{array}$ & $\begin{array}{l}\text { Not essential for EM } \\
\text { PoCUS at this time }\end{array}$ \\
\hline \multirow[t]{13}{*}{ Administration } & - & Administrative & Administrative & \\
\hline & & Directly observe learners & Teach ultrasonography courses & \\
\hline & & scanning & Publish original research & \\
\hline & & & Supervise research projects & \\
\hline & & & Provide physician credentialing & \\
\hline & & & $\begin{array}{l}\text { Manage a quality assurance } \\
\text { program }\end{array}$ & \\
\hline & & & Equipment purchasing & \\
\hline & & & Equipment maintenance & \\
\hline & & & Manage image archiving & \\
\hline & & & Curriculum development & \\
\hline & & & $\begin{array}{l}\text { Involvement with national } \\
\text { organizations }\end{array}$ & \\
\hline & & & $\begin{array}{l}\text { Develop and maintain an } \\
\text { ultrasonography fellowship }\end{array}$ & \\
\hline & & & $\begin{array}{l}\text { Understand billing for } \\
\text { ultrasonography }\end{array}$ & \\
\hline
\end{tabular}

identifying a competency as being less essential than residents and/or experts.

Table 4 provides the results from the needs assessment for EM-PoCUS fellowship training. Eighty-seven percent of respondents felt that there was a need for EM-PoCUS fellowship, and 56\% of respondents indicated that 6 months was the ideal length for such a fellowship. The responses of all groups indicated a perceived need for PoCUS fellows across all practice settings. There was significant variation in the number of fellowship training slots deemed to be required nationally.

A sensitivity analysis, in which the results were analyzed giving equal consideration to each of the three groups of responders rather than the predefined weighting for the expert group, found only minor differences in what was considered to be a nonessential competency and essential to fellowship training.

\section{DISCUSSION}

This is the first national needs assessment of major EM stakeholders to ascertain the competencies deemed necessary for a Canadian expert EM-PoCUS training curriculum. Eighty-seven percent of participants indicated that a need exists for EM-PoCUS fellowship training, and there was a general sense that PoCUS fellowship-trained emergency physicians are required to work in a variety of practice settings. Fellowship training was felt to require achievement of specific competencies beyond those of advanced or indepenent practitioners. Competencies identified as unique for EM-PoCUS fellowship primarily involved administrative and academic responsibilities, including machine purchasing and maintenance, organization and management of a quality assurance program, training and education, research, and advocacy.

With the number of EM-PoCUS fellowship programs offered in Canada increasing, a systematic and organized approach to obtaining expertise could be developed based on competencies we identified. It is expected that many EM residents will undertake not only general PoCUS training but also advanced training during their residency. Fellowship training including clinical applications, academic expertise, and administrative roles would require between 6 and 12 months of time depending on the objectives of the program. The option for RCPSC EM residents to commence advanced training in an area of focus within EM during their PGY4 year provides them with a unique opportunity to gain this experience. Fellowship training should also be available for practicing emergency physicians.

The items categorized by stakeholders as nonessential for EM practice may reflect the lack of evidence, 


\begin{tabular}{|c|c|c|c|}
\hline & Experts & Program directors & Residents \\
\hline Indicated a need exists for an EM-PoCUS fellowship, $n(\%)$ & $120(78.9)$ & $12(80)$ & $172(85.6)$ \\
\hline $\begin{array}{l}\text { Indicated they would have done an EM-PoCUS fellowship if it had been } \\
\text { available, } n(\%)\end{array}$ & $83(69.1)$ & $4(26.6)$ & $79(41.1)$ \\
\hline \multicolumn{4}{|l|}{ Ideal length of fellowship, $n(\%)$} \\
\hline $3 \mathrm{mo}$ & $27(22.5)$ & $1(8.3)$ & $51(25.8)$ \\
\hline $6 \mathrm{mo}$ & $65(54.2)$ & $8(66.6)$ & $91(46)$ \\
\hline $12 \mathrm{mo}$ & $27(22.5)$ & $3(25)$ & $54(27.3)$ \\
\hline $18 \mathrm{mo}$ & $1(0.8)$ & 0 & $1(0.5)$ \\
\hline $24 \mathrm{mo}$ & 0 & 0 & $1(0.5)$ \\
\hline \multicolumn{4}{|l|}{ Number of fellows who should be trained in Canada annually, $n(\%)$} \\
\hline $0-3$ & $5(4.2)$ & $1(8.3)$ & $22(11.2)$ \\
\hline $4-6$ & $37(30.8)$ & $4(33.3)$ & $48(24.4)$ \\
\hline $7-9$ & $18(15)$ & $2(16.6)$ & $42(21.3)$ \\
\hline $10-13$ & $20(16.6)$ & $3(25)$ & $36(18.3)$ \\
\hline$>13$ & 40 (33.3) & $2(16.6)$ & $49(24.9)$ \\
\hline \multicolumn{4}{|l|}{ Location of need for EM-PoCUS fellows } \\
\hline Rural & $62(15.3)$ & $6(15.8)$ & $91(15.4)$ \\
\hline Community & $81(20)$ & $7(18.4)$ & $120(21.0)$ \\
\hline Urban & $94(23.2)$ & $10(26.3)$ & $126(22)$ \\
\hline Academic & $104(25.7)$ & $11(28.9)$ & $151(26.4)$ \\
\hline Internationally & $64(15.8)$ & $4(10.5)$ & $84(14.7)$ \\
\hline
\end{tabular}

lack of urgency of the indication, or availability of alternatives to PoCUS. The use of EM-PoCUS for extremity fractures was identified as nonessential to EM practice, although some have deemed it essential for those practicing in remote environments without easy access to $\mathrm{x}$-ray equipment. 22,36 This discrepancy likely reflects the fact that most of our participants work in urban/suburban environments.

Many pediatric PoCUS competencis were categorized as nonessential. This likely reflects the limited evidence for emergency physicians using PoCUS in children and the nascent status of PoCUS training in pediatric EM fellowships. ${ }^{30-32}$ As we did not ask the resident group which population of EM patients they see most commonly, it is possible that those caring for pediatric patients were underrepresented. The lack of endorsement for pediatric competencies may also have arisen from our ommision of pediatric EM specialists and fellows in the study population. It is conceivable that as PoCUS evolves and training becomes more accessible, some of the pediatric indications (such as hypertrophic pyloric stenosis or intussuception) may become more applicable to general or advanced EM practice. The same is potentially true for pediatric procedural competencies (such as paracentesis, peripheral line placement, abscess drainage, and foreign body removal). ${ }^{33-37}$
The EM-PoCUS competencies currently endorsed by the RCPSC and CFPC were deemed by the partipants to be essential to general EM practice. This is likely a result of the national courses offered in Canada and PoCUS training EM residents receive in Canada. This training differs from that in the United States, where guidelines include renal and gallbladder ultrasonography as part of the primary/basic indications for EM-PoCUS. ${ }^{1}$

The category of advanced EM-PoCUS practice contained the greatest number of competencies with discrepancies. All 16 of 83 competencies with significant gap scores arose from PDs identifying a competency as being less essential compared to residents and/or experts. This may be because PDs typically have a broader view on various fellowship needs and may be reluctant to add additional required content into an already crowded training period. In addition, it is noteworthy that $30 \%$ of PDs were not credentialed in EM-PoCUS, a situation potentially arising from, or leading to, a negative perception of EM-PoCUS.

Some competencies were categorized in a manner conflicting with the current EM literature. For example, recent research has found that EM-PoCUS is superior to $\mathrm{x}$-ray for the diagnosis of pneumothorax 
and pleural effusions, ${ }^{38-40}$ yet this competency was categorized as being essential for advanced practitioners only. Similarly, the assessment of lower extremity deep vein thrombosis with PoCUS was categorized as being essential to fellowship-trained practitioners only; however, recent publications have shown this to be a quick, reliable, time- and costeffective technique that can be easily performed by general emergency physicians. ${ }^{41,42}$

\section{LIMITATIONS}

Our study has limitations and potential biases common to survey methodology. Although the survey instrument was pilot tested in an effort to eliminate ambiguous, confusing, or prejudicial items, response bias may have influenced our findings. It is possible, for example, that participants looked more favourably on PoCUS because $43 \%$ of them were experts in the field. Since many experts also derive income from teaching EM-PoCUS courses, and in some Canadian provinces, emergency physicians can bill for PoCUS, it is possible that one or both of these factors influenced the competencies that were endorsed. We were unable to determine whether differences existed between responders who were RCPSC EM trained compared to CFPC EM trained. Similarly, we were unable to determine whether differences existed between responders based on their level of training in residency, and it is possible that more senior residents view the role of PoCUS differently from their junior counterparts.

Our findings represent one point in time. Curricula evolve, and advances in clinical practice, education, and training, and research in EM-PoCUS will undoubtedly result in changes in competencies and expectations in this dynamic area of EM. It appears that PoCUS will continue to grow and be applied to an increasingly broad spectrum of clinical encounters in EM. Future challenges include maintaining high standards of training among practitioners and training expert leaders in this field. Competencies for different levels of practitioners need to be elucidated and applied nationally, and our hope is that the results of this study will help inform these important decisions.

\section{CONCLUSION}

This is the first needs assessment of major stakeholders in Canada to identify competencies for expert training in EM PoCUS. The competencies should form the basis for EM-PoCUS fellowship programs in Canada.

Competing interests: The research reported in this publication received financial support from the Department of Emergency Medicine, University of Ottawa. Dr. Michael Woo receives a salary as fellowship director from the Department of Emergency Medicine and has received speaking fees as an EDE2 and CAEP EDTU instructor. Dr. Ray Wiss receives a salary as fellowship program co-director from the Department of Emergency Medicine, NOSM, and receives a salary as the director of the EDE course. Dr. Steve Socransky receives a salary as fellowship program co-director from the Department of Emergency Medicine, NOSM, and has received speaking fees as the director of the EDE2 course.

\section{REFERENCES}

1. American College of Emergency Physicians. Emergency ultrasound guidelines. Available at: http://www.acep.org/WorkArea/ linkit.aspx?LinkIdentifier-id\&ItemID =32878 (accessed December 6, 2012).

2. Moore CL, Copel JA. Point-of-care ultrasonography. $N$ Engl 7 Med 2011;364:749-57, doi:10.1056/NEJMra0909487.

3. Canadian Association of Emergency Physicians. Use of point of care ultrasound by emergency physicians. 2012 position statement. Available at: http://www.cjem-online.ca/v14/n2/ p106 (accessed December 10, 2012).

4. Mateer JR, Aiman EJ, Brown MH, Olson DW. Ultrasonographic examination by emergency physicians of patients at risk for ectopic pregnancy. Acad Emerg Med 1995; 2:867-73, doi:10.1111/j.1553-2712.1995.tb03099.x.

5. Blaivas M, Harwood RA, Lambert MJ. Decreasing length of stay with emergency ultrasound examination of the gallbladder. Acad Emerg Med 1999;6:1020-3, doi:10.1111/j.15532712.1999.tb01186.x.

6. McKenney MG. 1,000 consecutive ultrasounds for blunt abdominal trauma. I Trauma 1996;40:607-10; discussion 611-2, doi:10.1097/00005373-199604000-00015.

7. Randolph AG, Cook DJ, Gonzales CA, Pribble CG. Ultrasound guidance for placement of central venous catheters: a meta-analysis of the literature. Crit Care Med 1996;24:2053-8, doi:10.1097/00003246-199612000-00020.

8. Hoppman R, Blaivas M, Elbarbary M. Better medical education and health care through point-of-care ultrasound. Acad Med 2012;87:134, doi:10.1097/ACM.0b013e31823f0e8f.

9. Rippey JC, Royse AG. Ultrasound in trauma [review]. Best Pract Res Clin Anaesthesiol 2009;23:343-62, doi:10.1016/ j.bpa.2009.02.011.

10. Modayil V, Ash A, Raio C. Cervical ectopic pregnancy diagnosed by point-of-care emergency department ultrasound. 7 Emerg Med 2011;41:655-7, doi:10.1016/ j.jemermed.2011.05.048.

11. Abu-Zidan FM. Point-of-care ultrasound in critically ill patients: where do we stand? 7 Emerg Trauma Shock 2012;5: 70-1, doi:10.4103/0974-2700.93120.

12. Royal College of Physicians and Surgeons of Canada. Objectives of training in emergency medicine. Available at: 
http://rcpsc.medical.org/residency/certification/objectives/ emergmed_e.pdf (accessed December 10, 2012).

13. Mackey DS, Steiner IP, editors. National guidelines: family medicine - emergency medicine residency programs. Available at: http://www.cfpc.ca/uploadedFiles/Education/FamilyMedE MResidencyPrograms(1).pdf (accessed December 10, 2012).

14. Canadian Emergency Ultrasound Society. Recommended standards. Available at: http://ceus.ca/002-standards/002-00. standards.htm (accessed December 10, 2012).

15. Society for Academic Emergency Medicine. Ultrasound position statement. SAEM Newsletter 1991;3:3.

16. Emergency Ultrasound Fellowships. EUS fellowship programs. Available at: http://eusfellowships.com/programs. php (accessed December 10, 2012).

17. Blaivas M, Theodoro DL, Sierzenski P. Proliferation in ultrasound fellowships in emergency medicine: how do we ensure future experts are expertly trained? Acad Emerg Med 2002;9:863-4, doi:10.1111/j.1553-2712.2002.tb02181.x.

18. Kim DJ, Theoret J, Liao MM, et al. The current state of ultrasound training in Canadian emergency medicine programs: perspectives from program directors. Acad Emerg Med 2012;19:1073-8, doi:10.1111/j.1553-2712.2012.01430.x.

19. Counselman FL, Sanders A, Slovis CM, et al. The status of bedside ultrasonography training in emergency medicine residency programs. Acad Emerg Med 2003;10:37-42, doi:10.1111/j.1553-2712.2003.tb01974.x.

20. Ahern M, Mallin MP, Weitzel S, et al. Variability in ultrasound education among emergency medicine residencies. West 7 Emerg Med 2010;11:314-8.

21. Akhtar S, Theodoro D, Gaspari R, et al. Resident training in emergency ultrasound: consensus recommendations from the 2008 Council of Emergency Medicine Residency Directors Conference. Acad Emerg Med 2009;16 Suppl 2: S32-6, doi:10.1111/j.1553-2712.2009.00589.x.

22. Sippel S, Muruganandan K, Levine A, Shah S. Review article: use of ultrasound in the developing world. Int 7 Emerg Med 2011;4:72, doi:10.1186/1865-1380-4-72.

23. Heegeman DJ, Burney KJ. Learning curves, credentialing, and the need for ultrasound fellowships. Acad Emerg Med 2003;10: 404-5, doi:10.1111/j.1553-2712.2003.tb01359.x.

24. Via G, Storti E, Spreafico A, et al. Point of care ultrasound for sepsis management in resource-limited settings: time for a new paradigm for global health care. Intensive Care Med 2012;38:1405-7, doi:10.1007/s00134-012-2606-0.

25. Sherbino J, Lockyer J. Mind the gap: educational needs assessment. In: Sherbino J, Frank JR, editors. Educational design: a CanMEDS guide for the bealth professions. Ottawa: Royal College of Physicians and Surgeons of Canada; 2011.

26. Laxdal OE. Needs assessment in continuing medical education: a practical guide. 7 Med Educ 1982;57:827-34.

27. Canadian Resident Matching Service. Available at: www. carms.ca (accessed December 10, 2012).

28. Dillman D. Mail and telephone surveys: the total design method. New York: Wiley; 1978.
29. Dillman D, Smyth M. Design effects in the transition to web-based surveys. Am 7 Prev Med 2007;32(5 Suppl):S90-6, doi:10.1016/j.amepre.2007.03.008.

30. Ramirez-Schrempp D, Dorfman DH, Tien I, Liteplo AS. Bedside ultrasound in pediatric emergency medicine fellowship programs in the United States: little formal training. Pediatr Emerg Care 2008;24:664-7, doi:10.1097/PEC. 0b013e3181884955.

31. Lambert RL, Boker JR, Maffei FA. National survey of bedside ultrasound use in pediatric critical care. Pediatr Crit Care Med 2011;12:655-9, doi:10.1097/PCC.0b013e 3182266a51.

32. Chamberlain MC, Reid SR, Madhok M. Utilization of emergency ultrasound in pediatric emergency departments. Pediatr Emerg Care 2011;27:628-32, doi:10.1097/PEC. 0b013e3182259908.

33. Lamperti $M$, Bodenham AR, Pittiruti $M$, et al. International evidence-based recommendations on ultrasound-guided vascular access. Intensive Care Med 2012;38:1105-17, doi:10. 1007/s00134-012-2597-x.

34. Malcom GE, Raio CC, Del Rios M, et al. Feasibility of emergency physician diagnosis of hypertrophic pyloric stenosis using point-of-care ultrasound: a multi-center case series. 7 Emerg Med 2009;37:283-6, doi:10.1016/ j.jemermed.2007.11.053.

35. Paziana K, Fields JM, Rotte M, et al. Soft tissue foreign body removal technique using portable ultrasonography. Wilderness Environ Med 2012;23:343-8, doi:10.1016/ j.wem.2012.04.006.

36. Taggart I, Voskoboynik N, Shah S, Liebmann O. ED pointof-care ultrasound in the diagnosis of ankle fractures in children. Am 7 Emerg Med 2012;30:1328.e1-3, doi:10.1016/ j.ajem.2011.06.037.

37. Halm BM, Boychuk RB, Franke AA. Diagnosis of intussusception using point-of-care ultrasound in the pediatric ED: a case report. Am 7 Emerg Med 2011;29:354.e1-3, doi:10.1016/ j.ajem.2010.03.016.

38. Alrajhi K, Woo MY, Vaillancourt C. Test characteristics of ultrasonography for the detection of pneumothorax: a systematic review and meta-analysis. Chest 2012;141:703-8, doi:10.1378/chest.11-0131.

39. Volpicelli G, Ebarbary M, Blaivas M, et al. International evidence-based recommendations for point-of-care lung ultrasound. Intensive Care Med 2012;38:577-91, doi:10. 1007/s00134-012-2513-4.

40. Agricola E, Arbelot C, Blaivas M, et al. Ultrasound performs better than radiographs. Thorax 2011;66:828-9, doi:10.1136/ thx.2010.153239.

41. Blaivas M. Point-of-care ultrasonographic deep venous thrombosis evaluation after just ten minutes training: is this offer too good to be true? Ann Emerg Med 2010;56:611-3, doi:10.1016/j.annemergmed.2010.08.014.

42. Blaivas $M$. Ultrasound in the detection of venous thromboembolism. Crit Care Med 2007;35(5 Suppl):S224-34, doi:10.1097/01.CCM.0000260672.13913.FD. 


\section{Designing an Emergency Medicine Ultrasonography Fellowship in Canada: National Survey of Stakeholders}

Thank you in advance for completing this survey. For each survey we receive from your residency program, a ballot will be entered in a draw for $\$ 500$ to be used towards a resident social event.

Completing all three sections should take approximately 15 minutes. You will notice a table of various competencies we are interested in assessing. Please do complete to the end. Responses will be anonymously collected.

\section{A: DEMOGRAPHICS}

1. What is your gender? Please circle.

$$
\begin{aligned}
& M \\
& F
\end{aligned}
$$

2. What year were you born?

3. What year of residency are you currently completing? Please circle.

$$
\begin{aligned}
& \text { Medical student } \\
& P G Y-1 \\
& P G Y-2 \\
& P G Y-3 \\
& P G Y-4 \\
& P G Y-5
\end{aligned}
$$

4. Which residency program are you registered in?

5. What university are you completing your residency at?

6. Which of the following reflects your level of training with EMUS? Please circle.

\section{no formal training}

introductory training

credentialed

advanced training

other (please list):

\section{B: NEEDS ASSESSMENT}

1. Is there a need for an EMUS fellowship in Canada? Please circle.

Y

$N$

2. Would you have done an EMUS fellowship had it been widely available? Please circle.

Y

$N$

3. What is the ideal length for an EMUS fellowship?
3 months
6 months
12 months
18 months
24 months

4. How many EMUS fellows should be trained per year in Canada?

$0-3$

4-6

7-9

$10-13$

greater than 13

5. Where is there a need for EMUS fellowship graduates? You may select more than one answer:

rural hospitals

community hospitals

urban centres

academic centres

internationally

\section{C: COMPETENCIES}

Please select the lowest level of EMUS training required for each competency.

Ex: 


\begin{tabular}{|c|c|c|c|c|}
\hline COMPETENCY & $\begin{array}{l}\text { NOT ESSENTIAL TO } \\
\text { ANY EM PRACTICE }\end{array}$ & $\begin{array}{l}\text { ESSENTIAL TO } \\
\text { GENERAL EM } \\
\text { PRACTICE }\end{array}$ & $\begin{array}{l}\text { ESSENTIAL TO } \\
\text { ADVANCED EMUS } \\
\text { TRAINING }\end{array}$ & $\begin{array}{l}\text { ESSENTIAL TO } \\
\text { EMUS FELLOWSHIP } \\
\text { TRAINED }\end{array}$ \\
\hline Trauma & & $\mathbf{x}$ & & \\
\hline COMPETENCY & $\begin{array}{l}\text { NOT ESSENTIAL TO } \\
\text { ANY EM PRACTICE }\end{array}$ & $\begin{array}{l}\text { ESSENTIAL TO } \\
\text { GENERAL EM } \\
\text { PRACTICE }\end{array}$ & $\begin{array}{l}\text { ESSENTIAL TO } \\
\text { ADVANCED EMUS } \\
\text { TRAINING }\end{array}$ & $\begin{array}{l}\text { ESSENTIAL TO } \\
\text { EMUS FELLOWSHIP } \\
\text { TRAINED }\end{array}$ \\
\hline $\begin{array}{l}\text { CLINICAL } \\
\text { SCENARIOS }\end{array}$ & & & & \\
\hline Trauma & & & & \\
\hline Cardiac arrest & & & & \\
\hline Undifferentiated shock & & & & \\
\hline $\begin{array}{l}\text { Undifferentiated } \\
\text { shortness of breath }\end{array}$ & & & & \\
\hline $\begin{array}{l}\text { Undifferentiated chest } \\
\text { pain }\end{array}$ & & & & \\
\hline $\begin{array}{l}\text { Undifferentiated } \\
\text { abdominal pain }\end{array}$ & & & & \\
\hline PHYSICS & & & & \\
\hline $\begin{array}{l}\text { Understanding of } \\
\text { relationship between } \\
\text { frequency, penetration } \\
\text { and resolution }\end{array}$ & & & & \\
\hline $\begin{array}{l}\text { Understanding } \\
\text { differences in } \\
\text { transducers }\end{array}$ & & & & \\
\hline Use of M-Mode & & & & \\
\hline Use of Doppler & & & & \\
\hline $\begin{array}{l}\text { Understanding image } \\
\text { artefacts }\end{array}$ & & & & \\
\hline Basic knobology & & & & \\
\hline CARDIAC US & & & & \\
\hline Pericardial effusion & & & & \\
\hline $\begin{array}{l}\text { Confirmation of } \\
\text { asystole }\end{array}$ & & & & \\
\hline $\begin{array}{l}\text { Assessment of global } \\
\text { cardiac activity }\end{array}$ & & & & \\
\hline $\begin{array}{l}\text { Assessment of inferior } \\
\text { vena cava for volume } \\
\text { status }\end{array}$ & & & & \\
\hline
\end{tabular}




\begin{tabular}{|c|c|c|c|c|}
\hline & $\begin{array}{l}\text { NOT ESSENTIAL TO } \\
\text { ANY EM PRACTICE }\end{array}$ & $\begin{array}{l}\text { ESSENTIAL TO } \\
\text { GENERAL EM } \\
\text { PRACTICE }\end{array}$ & $\begin{array}{l}\text { ESSENTIAL TO } \\
\text { ADVANCED EMUS } \\
\text { TRAINING }\end{array}$ & $\begin{array}{l}\text { ESSENTIAL TO } \\
\text { EMUS FELLOWSHIP } \\
\text { TRAINED }\end{array}$ \\
\hline \multicolumn{5}{|l|}{$\begin{array}{l}\text { Assessment of wall } \\
\text { motion abnormalities }\end{array}$} \\
\hline CHEST US & & & & \\
\hline \multicolumn{5}{|l|}{ Pneumothorax } \\
\hline \multicolumn{5}{|l|}{ Pulmonary edema } \\
\hline \multicolumn{5}{|l|}{ Pleural effusion } \\
\hline \multicolumn{5}{|l|}{ VASCULAR US } \\
\hline \multicolumn{5}{|l|}{$\begin{array}{l}\text { Abdominal aortic } \\
\text { aneurysm (AAA) }\end{array}$} \\
\hline \multicolumn{5}{|l|}{ Upper extremity DVT } \\
\hline \multicolumn{5}{|l|}{ Lower extremity DVT } \\
\hline \multirow{2}{*}{\multicolumn{5}{|c|}{$\begin{array}{l}\text { Acute arterial } \\
\text { occlusion } \\
\text { OBS-GYN US }\end{array}$}} \\
\hline & & & & \\
\hline \multicolumn{5}{|l|}{$\begin{array}{l}1^{\text {st }} \text { trimester } \\
\text { intrauterine pregnancy } \\
\text { using transabdominal } \\
\text { view }\end{array}$} \\
\hline \multicolumn{5}{|l|}{$\begin{array}{l}1^{\text {s }} \text { trimester } \\
\text { intrauterine pregnancy } \\
\text { using transvaginal } \\
\text { view }\end{array}$} \\
\hline \multicolumn{5}{|l|}{ Ovarian torsion } \\
\hline \multicolumn{5}{|l|}{ Ovarian cyst } \\
\hline \multicolumn{5}{|l|}{ Tubo-ovarian abscess } \\
\hline \multicolumn{5}{|l|}{$\begin{array}{l}\text { Assessment of fetal } \\
\text { heart rate using M- } \\
\text { Mode }\end{array}$} \\
\hline \multicolumn{5}{|l|}{$\begin{array}{l}\text { Assessment of pelvic } \\
\text { inflammatory disorder }\end{array}$} \\
\hline \multicolumn{5}{|l|}{ TESTICULAR US } \\
\hline \multicolumn{5}{|l|}{ Testicular torsion } \\
\hline \multicolumn{5}{|l|}{ Epidydimitis- orchitis } \\
\hline \multicolumn{5}{|l|}{ Hydrocoele } \\
\hline \multicolumn{5}{|l|}{ Testicular trauma } \\
\hline \multicolumn{5}{|l|}{ testicular mass } \\
\hline \multicolumn{5}{|l|}{ ABDOMINAL US } \\
\hline \multicolumn{5}{|l|}{ Cholecystitis } \\
\hline Choledocholithiasis & & & & \\
\hline
\end{tabular}




\begin{tabular}{|c|c|c|c|c|}
\hline & $\begin{array}{l}\text { NOT ESSENTIAL TO } \\
\text { ANY EM PRACTICE }\end{array}$ & $\begin{array}{l}\text { ESSENTIAL TO } \\
\text { GENERAL EM } \\
\text { PRACTICE }\end{array}$ & $\begin{array}{l}\text { ESSENTIAL TO } \\
\text { ADVANCED EMUS } \\
\text { TRAINING }\end{array}$ & $\begin{array}{l}\text { ESSENTIAL TO } \\
\text { EMUS FELLOWSHIP } \\
\text { TRAINED }\end{array}$ \\
\hline \multicolumn{5}{|l|}{ Appendicitis } \\
\hline \multicolumn{5}{|l|}{ Diverticulitis } \\
\hline \multicolumn{5}{|l|}{ Bowel obstruction } \\
\hline \multicolumn{5}{|l|}{ Pancreatitis } \\
\hline \multicolumn{5}{|l|}{ Intussuception } \\
\hline \multicolumn{5}{|l|}{$\begin{array}{l}\text { Hypertrophic pyloric } \\
\text { stenosis }\end{array}$} \\
\hline \multicolumn{5}{|l|}{$\begin{array}{l}\text { Abdominal/inguinal } \\
\text { hernias }\end{array}$} \\
\hline \multicolumn{5}{|l|}{ SOFT TISSUE US } \\
\hline \multicolumn{5}{|l|}{ Cutaneous abscess } \\
\hline \multicolumn{5}{|l|}{ Peritonsillar abscess } \\
\hline \multicolumn{5}{|l|}{$\begin{array}{l}\text { Foreign body } \\
\text { localization in soft } \\
\text { tissues }\end{array}$} \\
\hline \multicolumn{5}{|l|}{ MSK US } \\
\hline \multicolumn{5}{|l|}{ Achilles tendon tears } \\
\hline \multicolumn{5}{|l|}{ Rotator cuff tears } \\
\hline \multicolumn{5}{|l|}{ Extremity fractures } \\
\hline \multicolumn{5}{|l|}{ Joint effusions } \\
\hline \multicolumn{5}{|l|}{ OCULAR US } \\
\hline \multicolumn{5}{|l|}{$\begin{array}{l}\text { Optic nerve sheath } \\
\text { diameter for } \\
\text { intracranial pressure }\end{array}$} \\
\hline \multicolumn{5}{|l|}{ Retinal detachment } \\
\hline \multicolumn{5}{|l|}{$\begin{array}{l}\text { Posterior vitreous } \\
\text { detachment }\end{array}$} \\
\hline \multicolumn{5}{|l|}{$\begin{array}{l}\text { Foreign body } \\
\text { localization in eye }\end{array}$} \\
\hline \multicolumn{5}{|l|}{$\begin{array}{l}\text { Retrobulbar } \\
\text { hematoma }\end{array}$} \\
\hline \multirow{2}{*}{\multicolumn{5}{|c|}{\begin{tabular}{|l|} 
PROCEDURAL US \\
Using US for.... \\
Central line placement
\end{tabular}}} \\
\hline & & & & \\
\hline \multicolumn{5}{|l|}{$\begin{array}{l}\text { Peripheral line } \\
\text { placement }\end{array}$} \\
\hline \multicolumn{5}{|l|}{ Arterial line placement } \\
\hline \multicolumn{5}{|l|}{ Thoracentesis } \\
\hline Paracentesis & & & & \\
\hline
\end{tabular}




\begin{tabular}{|c|c|c|c|c|}
\hline & $\begin{array}{l}\text { NOT ESSENTIAL TO } \\
\text { ANY EM PRACTICE }\end{array}$ & $\begin{array}{l}\text { ESSENTIAL TO } \\
\text { GENERAL EM } \\
\text { PRACTICE } \\
\end{array}$ & $\begin{array}{l}\text { ESSENTIAL TO } \\
\text { ADVANCED EMUS } \\
\text { TRAINING }\end{array}$ & $\begin{array}{l}\text { ESSENTIAL TO } \\
\text { EMUS FELLOWSHIP } \\
\text { TRAINED }\end{array}$ \\
\hline \multicolumn{5}{|l|}{ Pericardiocentesis } \\
\hline \multicolumn{5}{|l|}{ Arthrocentesis } \\
\hline \multicolumn{5}{|l|}{ Abscess drainage } \\
\hline \multicolumn{5}{|l|}{ Lumbar puncture } \\
\hline \multicolumn{5}{|l|}{$\begin{array}{l}\text { Confirm ETT } \\
\text { placement }\end{array}$} \\
\hline \multicolumn{5}{|l|}{$\begin{array}{l}\text { Confirm pacemaker } \\
\text { placement }\end{array}$} \\
\hline \multicolumn{5}{|l|}{ Regional anesthesia } \\
\hline \multicolumn{5}{|l|}{ Hematoma blocks } \\
\hline \multicolumn{5}{|l|}{ Foreign body removal } \\
\hline \multicolumn{5}{|l|}{ TEACHING } \\
\hline \multicolumn{5}{|l|}{$\begin{array}{l}\text { Directly observe } \\
\text { learners scanning }\end{array}$} \\
\hline \multicolumn{5}{|l|}{$\begin{array}{l}\text { Teach ultrasound } \\
\text { courses }\end{array}$} \\
\hline \multicolumn{5}{|l|}{ RESEARCH } \\
\hline \multicolumn{5}{|l|}{$\begin{array}{l}\text { Publish original } \\
\text { research }\end{array}$} \\
\hline \multicolumn{5}{|l|}{$\begin{array}{l}\text { Supervise research } \\
\text { projects }\end{array}$} \\
\hline \multicolumn{5}{|l|}{ ADMINISTRATIVE } \\
\hline \multicolumn{5}{|l|}{$\begin{array}{l}\text { Provide physician } \\
\text { credentialing }\end{array}$} \\
\hline \multicolumn{5}{|l|}{$\begin{array}{l}\text { Organize and manage } \\
\text { a quality assurance } \\
\text { program }\end{array}$} \\
\hline \multicolumn{5}{|l|}{ Equipment purchasing } \\
\hline \multicolumn{5}{|l|}{$\begin{array}{l}\text { Equipment } \\
\text { maintenance }\end{array}$} \\
\hline \multicolumn{5}{|l|}{$\begin{array}{l}\text { Manage image } \\
\text { archiving }\end{array}$} \\
\hline \multicolumn{5}{|l|}{$\begin{array}{l}\text { Curriculum } \\
\text { development }\end{array}$} \\
\hline \multicolumn{5}{|l|}{$\begin{array}{l}\text { Involvement with } \\
\text { national organizations } \\
\text { that promote } \\
\text { ultrasound }\end{array}$} \\
\hline \multicolumn{5}{|l|}{$\begin{array}{l}\text { Develop and maintain } \\
\text { an US fellowship }\end{array}$} \\
\hline $\begin{array}{l}\text { Understand billing for } \\
\text { ultrasound }\end{array}$ & & & & \\
\hline
\end{tabular}




\section{A: DEMOGRAPHICS}

1. What is your gender? Please circle.

$$
\begin{aligned}
& M \\
& F
\end{aligned}
$$

2. What year were you born?

3. Which of the following describes your highest level of medical training? Circle all that apply:

Resident
Physician CCFP-EM
Physician CCFP (not-EM)
Physician (FRCP-EM), Other:

4. When did you graduate from residency?

5. What province do you practice in?

6. Which of the locations describes where you primarily practice emergency medicine? SELECT ONE:

inner city

urban/suburban

small town

rural

remote

other:
7. Which of the following best describes your primarily EM practice? SELECT ONE

low volume community $E D$

medium volume community ED

bigh volume community ED

teaching hospital ED

pediatric hospital ED

other:

8. Which of the following groups do you primarily see in your EM practice? SELECT ONE

adults

pediatrics

both adults and pediatrics

9. Which of the following reflects your level of training with EMUS? Please circle.

no formal training

introductory training

credentialed

advanced training

other (please list): 